\title{
Bacterial Infections and Antimicrobial Resistance Patterns of Burn Wound Infections: A One Year Study from Burn Hospital, Isfahan, Iran
}

\author{
Elham Haghighifar ${ }^{1}$ (D), Razie Kamali Dolatabadi*1 iD
}

\section{Dept. of Microbiology, School of Medicine, Isfahan University of Medical Sciences, Isfahan, Iran}

\begin{tabular}{l} 
Article Info \\
\hline doi 10.30699/jambs.28.128.144 \\
Received: 2019/12/26; \\
Accepted: 2020/02/15; \\
Published Online: 01 May 2020; \\
Use your device to scan and read the \\
article online
\end{tabular}

Corresponding Information:

Razie Kamali Dolatabadi

Dept. of Microbiology, School of Medicine, Isfahan University of Medical Sciences, Isfahan, Iran E-Mail:

r.kamali@resident.mui.ac.ir

\begin{abstract}
Background \& Objective: Infections due to burn wounds are serious because of their effects on the course of the disease and its consequences. The rate of burn wound infection is very high in developing countries. The purpose of this study was to identify common bacterial agents causing burn wound infection and determine antimicrobial susceptibility patterns in a burn Hospital, Isfahan, Iran.
\end{abstract}

Materials \& Methods: This cross-sectional study was conducted from 2017 to 2018 on all patients with burn wound infection. Burn wounds suspected of infection were collected aseptically and traditional bacteriological methods were used to identify the causes of infection. Antimicrobial resistance test was done by the disk diffusion method in accordance with CLSI recommendations.

Results: From the total of 1500 wound culture, 957(63.8\%) samples were detected as positive. The highest rate of infection was in the ICU ward and the lowest was in the restoration ward. The most common gram-negative bacteria were Acinetobacter baumannii (34.9\%) with the highest and the lowest antibiotic resistance to Ceftazidime and Tobramycin, respectively. Among recovered Gram-positive isolates, Staphylococcus aureus $(10.2 \%)$ were the predominant isolates with the highest and the lowest antibiotic resistance to Penicillin and Vancomycin, respectively.

Conclusion: Due to the variable nature of antibiotic susceptibility patterns and pathogens causing burn wound infection, continuous evaluation, detection of dominant bacterial infections and sensitivity patterns to locally available antibiotics in burn wound patients in order to modify the drug regimen for proper antibiotic treatment is important and seems reasonable.

Keywords: Antimicrobial resistance pattern, Bacterial infection, Burn patients

\section{Introduction}

Infections are a major public health problem in burn patients due to features such as the loss of the first line of defense against microbial invasion, the presence of abandoned and vascular tissue, changes in the specific and non-specific components of the immune system, and hospitalization. The hospital provides a good environment for infections to grow (1). Burn lesions are sterile from the beginning, but 48 hours later the wounds are colonized by gram-positive skin flora such as $\beta$-hemolytic streptococcus and Staphylococcus aureus bacteria $(2,3)$. After 2 to 3 days, the wounds are colonized with gram-negative bacteria in the patient's respiratory tract and gastrointestinal tract like the Pseudomonas aeruginosa, Klebsiella pneumoniae and Escherichia coli, as well as in the microorganisms of the hospital environment or hospital staff (4-9).

The world health organization (WHO) has estimated that the burn injury leads to annual 265,000 deaths, half of which occurred in the WHO south-east Asia region
(10). Long-term administration of antibiotics leads to the development of multidrug-resistant strains, which mainly belong to the: $S$. aureus, $P$. aeruginosa, and Acinetobacter baumannii (11). Multidrug-resistant organisms cause infections that are very difficult to treat because antimicrobial drugs are slightly effective in combating them (12). Since effective new antibiotics have not yet been developed, especially for gramnegative bacteria, efforts should be made to maintain the activity of existing antimicrobial drugs, fight against antimicrobial resistance and provide effective measures to control infection to prevent infection of patients with drug-resistant strains (13).

$P$. aeruginosa and $A$. baumannii, particularly in developing countries, are the most significant and common causes of important infections in burn patients (14-22). When P. aeruginosa and A. baumannii infect burn wounds, treatment becomes very complicated, especially if there is multidrug resistance and the 
mortality rate among patients is approximately $40-50 \%$ $(14,15,23,24)$. The problem of treating drug-resistant infections is increasing day by day (15-17). The major problem of infection control especially in developing countries is appearance of multi drug-resistant strains in burn wound infections. The aim of the present study was to investigate the prevalence of burn wound infections (BWI) in one of the main burn hospitals in the country and the measure antimicrobial resistance in this hospital for active treatment and emergency medicine.

\section{Materials and Methods}

\section{Sample Collection:}

The current study was conducted over a 12-month period (March 2017 to April 2018) at Imam Musa Kazem burn hospital in Isfahan, Iran. About 1500 burn wound samples were collected from the hospitalized patients (784 men and 716 women) in different wards of the hospital.

Sampling of the burn wound was performed after removing the dressings and removing local antibacterial agents and wound cleaning by washing with sterile saline solution $(0.9 \% \mathrm{NaCl})$.

In order to get enough cellular material for culture, the end of two sterile swabs were transmitted by at least one centimeter of the open wound. Adequate pressure should be applied to the tip of the swabs to bleed a little into the underlying tissue (24).

\section{Sample Processing}

The first swab was used for direct smear and gram staining to examine bacteria and diagnose PMNL, which is an important feature in the case of bacterial infection, which must be distinguished from bacterial cloning (23).

\section{Culture}

The swabs were cultured as streak on blood and MacConkey agar plates and incubated for $24 \mathrm{~h}$ of aerobic incubation at $37^{\circ} \mathrm{C}$. Conventional bacteriological methods (Gram-stain, catalase test, oxidase test, indole test, Methyl red (MR) and VogesProskauer (VP) test, Citrate test, urease test, coagulase test, Novobiocin resistance, Hemolysis type, Susceptibility to Bacitracin, Optochin, Hydrolysis of cAMP, Hydrolysis by Bile esculin, Growth in $6.5 \%$ $\mathrm{NaCl}$, oxidative-fermentative (OF) test, triple sugar iron agar (TSIA)) were done for the isolation and identification of the bacteria (25).

\section{Antibiotic Susceptibility Tests:}

Antimicrobial resistance tests were done according to clinical laboratory standards institute guidelines via Kirby-Bauer disk diffusion method. Their interpretation was based on the CLSI-2018 tables (26). Antibiotics included Ciprofloxacin $(5 \mu \mathrm{g})$, Amikacin $(30 \mu \mathrm{g})$, Ceftazidime $(30 \mu \mathrm{g})$, Nalidixic acid $(30 \mu \mathrm{g})$,
Piperacillin $(100 \mu \mathrm{g})$, Imipenem $(10 \mu \mathrm{g})$, Meropenem $(10 \mu \mathrm{g})$, and Vancomycin $(30 \mu \mathrm{g})$, Ceftriaxone $(30 \mu \mathrm{g})$, Penicillin (10 units), Piperacillin - Tazobactam $(100 / 10 \mu \mathrm{g})$, Tobramycin $(10 \mu \mathrm{g})$ (American Bidi). The test was performed on Mueller-Hinton agar (Merck, Germany). E. coli ATCC 25922 strain was used as a control (27).

Approval to conduct the study was obtained from the Research Ethics Committee of Isfahan University of Medical Sciences (ID- number: IR.MUI.RESEA RCH.REC.1397.114).

\section{Data Analysis:}

Data were analyzed via SPSS 24. (SPSS Inc., IL., USA). P-value $\leq 0.05$ was considered statistically significant.

\section{Results}

Of the 1500 cultured samples, 957 (63.8\%) included bacterial isolates and 543 wound swabs were $(36.2 \%)$ sterile.

\section{Bacterial Colonization Pattern of Burn Wounds Infections:}

Different types of bacterial isolates were isolated from burn wound infection and biopsy of burn wound infection, of which 146 were Gram positive and 815 were Gram negative.

The results clearly showed that $A$. baumannii with $34.7 \%$ frequency and $P$. aeruginosa with $29.6 \%$ frequency were the most common Gram-negative bacterial isolates and $S$. aureus with $10.2 \%$ frequency was the most common Gram-positive bacterial isolate (Table 1).

The prevalence of bacterial isolates among different wards of the hospital showed that burn wound infection was the most frequent in ICU patients $(50.2 \%)$ and the least in restoration patients $(6.6 \%)$ (Table 2).

According to the results, $50.7 \%$ of isolates showed MDR resistance. The results of antibiotic susceptibility tests showed that the most resistant isolates to 14 antibiotics examined were $A$. baumannii and $P$. aeruginosa isolates (Table 3).

\section{Antibiotic Resistances of $A$. baumannii:}

Among the A. baumannii isolates, the highest resistance to Ciprofloxacin $(91.9 \%)$ and then to Meropenem $(81.75 \%)$ were observed. The highest sensitivity to Tobramycin (56.9\%) was reported (Figure 1).

\section{Antibiotic Resistance of $P$. aeruginosa:}

Among $P$. aeruginosa isolates, the highest resistance to Ceftazidime (95.6\%) and then to Ciprofloxacin $(92.8 \%)$ were seen. The highest sensitivity to Amikacin (57.9\%) was found (Figure 1). 


\section{Antibiotic Resistance of S. aureus:}

Among S. aureus isolates, the highest resistance were seen to Penicillin $(63.2 \%)$ and then to
Ciprofloxacin (52\%). The highest sensitivity was found to be to Vancomycin (96\%) (Figure 2).

Table 1. Rate of bacterial pathogens isolated in burn patients

\begin{tabular}{lc}
\multicolumn{1}{c}{ Types of bacteria } & Percentage (number) \\
\hline A. baumannii & $34.9 \%(334)$ \\
\hline P. aeruginosa & $29.8 \%(285)$ \\
\hline S. aureus & $10.2 \%(98)$ \\
\hline K. pneumoniae & $8.3 \%(80)$ \\
\hline Other non-fermenting Gram-negative bacilli & $5.2 \%(50)$ \\
Coagulase-negative Staphylococcus sp. & $4.8 \%(46)$ \\
\hline E. cloacae & $3.4 \%(33)$ \\
\hline E. coli & $1.2 \%(10)$ \\
\hline Others Enteribacteriaceae & $1.3 \%(12)$ \\
\hline Enterococcus & $0.09(9)$ \\
\hline Total & $100 \%(957)$ \\
\hline
\end{tabular}

Table 2. Prevalence of bacterial infection among different wards of the hospital

\begin{tabular}{|lccccc|}
\hline \multicolumn{1}{c}{ Wards } & ICU & Emergency & Burn & Restoration & Total \\
\hline A. baumannii & 229 & 54 & 43 & 8 & 334 \\
\hline $\boldsymbol{P .}$ aeruginos & 171 & 57 & 50 & 7 & 285 \\
\hline S. aureus & 19 & 44 & 30 & 5 & 98 \\
\hline K. pneumoniae & 27 & 14 & 14 & 25 & 80 \\
\hline Other non-fermenting Gram-negative bacilli & 19 & 11 & 16 & 4 & 50 \\
\hline Coagulase-negative Staphylococcus sp. & 8 & 14 & 17 & 7 & 46 \\
\hline E. cloacae & 5 & 12 & 10 & 6 & 33 \\
\hline E. coli & 3 & 5 & 1 & 1 & 10 \\
\hline Others Enterobacteriaceae & 0 & 7 & 5 & 0 & 12 \\
\hline Enterococcus & 0 & 5 & 3 & 1 & 9 \\
\hline Total & $\mathbf{4 8 1}$ & $\mathbf{2 2 3}$ & $\mathbf{1 8 9}$ & $\mathbf{6 4}$ & $\mathbf{9 5 7}$
\end{tabular}

Table 3. Antimicrobial resistance pattern

\begin{tabular}{ccccccccccc}
$\begin{array}{c}\text { ANTIBUTICS } \\
\text { ISOLATES }\end{array}$ & A.baumanii & P.aeroginosa & S. aureus & K. pneunoniae & ONGNF & CON & E. cloacae & E. coli & OENT & Enterococcus \\
CP & 310 & 262 & 51 & 53 & 37 & 15 & 16 & 6 & 5 & 5 \\
& $(92.8 \%)$ & $(91.9 \%)$ & $(52 \%)$ & $(66.2 \%)$ & $(74 \%)$ & $(32.6 \%)$ & $(48.5 \%)$ & $(60 \%)$ & $(41.6 \%)$ & $(55.5 \%)$ \\
AN & 207 & 165 & 27 & 18 & 28 & 5 & 5 & 4 & 4 & 4 \\
& $(61.9 \%)$ & $(57.9 \%)$ & $(27.5 \%)$ & $(20 \%)$ & $(56 \%)$ & $(11 \%)$ & $(15 \%)$ & $(40 \%)$ & $(33.3 \%)$ & $(44.4 \%)$ \\
CAZ & 314 & 197 & $*$ & 15 & 27 & $*$ & 8 & 4 & 4 & $*$ \\
& $(95.6 \%)$ & $(69.1 \%)$ & & $(18.75 \%)$ & $(54 \%)$ & & $(24.2 \%)$ & $(40 \%)$ & $(33.3 \%)$ & $*$ \\
NA & $*$ & $*$ & 21 & $*$ & $*$ & 5 & 0 & $*$ & $*$ & $(44.4 \%)$ \\
\hline
\end{tabular}




\begin{tabular}{|c|c|c|c|c|c|c|c|c|c|c|}
\hline $\begin{array}{l}\text { ANTIBUTICS } \\
\text { ISOLATES }\end{array}$ & A.baumanii & P.aeroginosa & S. aureus & K.pneumoniae & ONGNF & $\mathrm{CON}$ & E. cloacae & E. coli & OENT & Enterococcus \\
\hline PIP & $\begin{array}{c}215 \\
(64.4 \%)\end{array}$ & $\begin{array}{c}196 \\
(68.7 \%)\end{array}$ & $\begin{array}{c}35 \\
(35.7 \%)\end{array}$ & $\begin{array}{c}14 \\
(17.5 \%)\end{array}$ & $\begin{array}{c}34 \\
(68 \%)\end{array}$ & $\begin{array}{c}10 \\
(22 \%)\end{array}$ & $\begin{array}{c}9 \\
(27.3 \%)\end{array}$ & $\begin{array}{c}3 \\
(30 \%)\end{array}$ & $4(33.3 \%)$ & $3(33.3 \%)$ \\
\hline IMP & $\begin{array}{c}223 \\
(66.7 \%)\end{array}$ & $\begin{array}{c}20 \\
3(71.2 \%)\end{array}$ & * & $\begin{array}{c}27 \\
(33.7 \%)\end{array}$ & $\begin{array}{c}31 \\
(62 \%)\end{array}$ & * & $\begin{array}{c}10 \\
(30 \%)\end{array}$ & $\begin{array}{c}4 \\
(40 \%)\end{array}$ & $\begin{array}{c}3 \\
(25 \%)\end{array}$ & $*$ \\
\hline MEN & $\begin{array}{c}220 \\
(65.8 \%)\end{array}$ & $\begin{array}{c}233 \\
(81.75 \%)\end{array}$ & * & $\begin{array}{c}38 \\
(47.5 \%)\end{array}$ & $\begin{array}{c}27 \\
(54 \%)\end{array}$ & $*$ & $\begin{array}{c}11 \\
(33.3 \%)\end{array}$ & $\begin{array}{c}4 \\
(40 \%)\end{array}$ & $\begin{array}{c}4 \\
(33.3 \%)\end{array}$ & $*$ \\
\hline V & $*$ & * & $8 \mathrm{I}$ & $*$ & * & 0 & $*$ & * & $*$ & 0 \\
\hline $\mathrm{CC}$ & $*$ & $*$ & $\begin{array}{c}27 \\
(27.5 \%)\end{array}$ & * & * & $\begin{array}{c}11 \\
(24 \%)\end{array}$ & $*$ & $*$ & $*$ & $\begin{array}{c}3 \\
(33.3 \%)\end{array}$ \\
\hline $\mathrm{CRO}$ & $\begin{array}{c}296 \\
(88.6 \%)\end{array}$ & $\begin{array}{c}209 \\
(73.33 \%)\end{array}$ & $*$ & $\begin{array}{c}41 \\
(51.2 \%)\end{array}$ & $\begin{array}{c}32 \\
(64 \%)\end{array}$ & $*$ & $\begin{array}{c}15 \\
(45.4 \%)\end{array}$ & $\begin{array}{c}7 \\
(70 \%)\end{array}$ & $\begin{array}{c}7 \\
(58.3 \%)\end{array}$ & $*$ \\
\hline $\mathrm{p}$ & * & $*$ & $\begin{array}{c}62 \\
(63.2 \%)\end{array}$ & $*$ & * & $\begin{array}{c}21 \\
(45.6 \%)\end{array}$ & * & $*$ & * & $\begin{array}{c}5 \\
(55.5 \%)\end{array}$ \\
\hline $\mathrm{TZP}$ & $\begin{array}{c}224 \\
(67 \%)\end{array}$ & $\begin{array}{c}188 \\
(65.9 \%)\end{array}$ & $*$ & $\begin{array}{c}28 \\
(35 \%)\end{array}$ & $\begin{array}{c}26 \\
(52 \%)\end{array}$ & $*$ & $\begin{array}{c}10 \\
(30 \%)\end{array}$ & $\begin{array}{c}1 \\
(10 \%)\end{array}$ & $\begin{array}{c}1 \\
(8.3 \%)\end{array}$ & * \\
\hline TOB & $\begin{array}{c}190 \\
(56.9 \%)\end{array}$ & $\begin{array}{c}230 \\
(80.7 \%)\end{array}$ & $\begin{array}{c}45 \\
(45.9 \%)\end{array}$ & $\begin{array}{c}13 \\
(16.3 \%)\end{array}$ & $\begin{array}{c}16 \\
(32 \%)\end{array}$ & $\begin{array}{c}5 \\
(11 \%)\end{array}$ & $\begin{array}{c}8 \\
(24.2 \%)\end{array}$ & $\begin{array}{c}2 \\
(20 \%)\end{array}$ & $\begin{array}{c}1 \\
(8.3 \%)\end{array}$ & $\begin{array}{c}4 \\
(44.4 \%)\end{array}$ \\
\hline
\end{tabular}

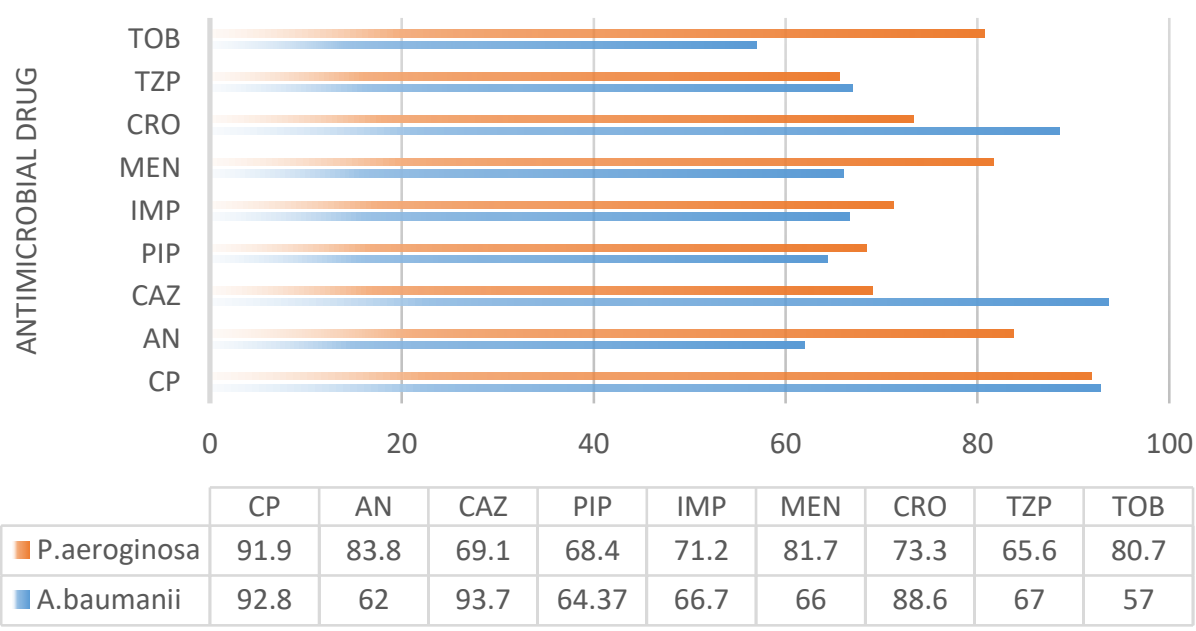

\%RESISTANCE

Figure 1. Resistance of $A$. baumannii and $P$. aeruginosa to antimicrobial drugs.

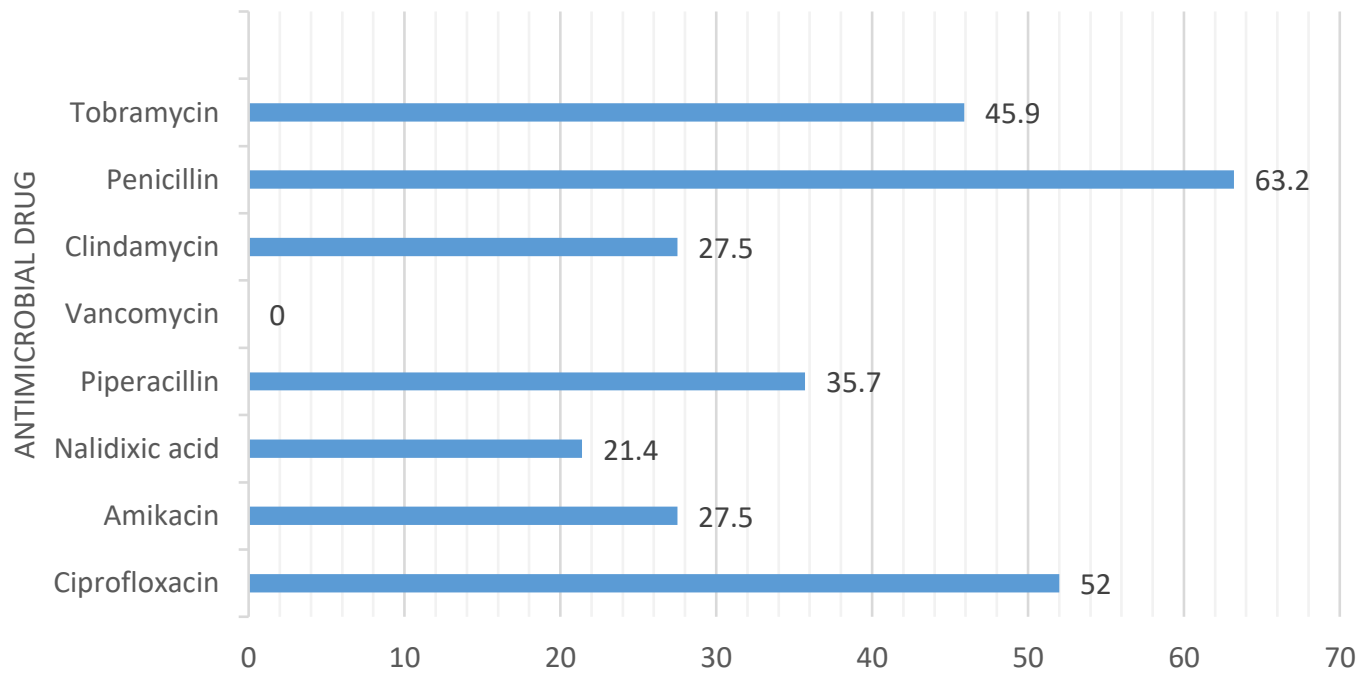

Figure 2. Resistance of S. aureus to antimicrobial drug. 


\section{Discussion}

Wound infection is one of the most common burn problems originating from nosocomial infections. The severity of infections in burn wounds is important because of their effects on the course of the disease and subsequently on patients. Most of the burn patients died of infection during the hospitalization. The prevalence of infections in burn wounds is high in developing countries because it is likely to decline the hygiene in poorer socioeconomic status. Malnutrition also plays an important role in the rapid acquisition of infection $(28,29)$. Families and hospital personals who are in closer contact with the patient may also be the source of the infection. Negligence towards the hygiene laws, lack of sterile bandages, clothing and patient care equipment, Long-term catheterization, and inadequate antibiotic treatment are among the most important causes of nosocomial infections (28). In the present study, the most common infections were $A$. baumannii (34.9\%), P. aeruginosa $(29.8 \%)$ and $S$. aureus (10.2\%). The results were similar to many studies showing that $A$. baumannii and $P$. aeruginosa are the most prevalent bacteria isolated from burn wounds (30); however, these results contradict with some other studies showing that $S$. aureus is the most common isolate $(\mathbf{2 8 , 3 1 )}$. A. baumannii is one of the most frequent nosocomial infection bacteria widely isolated from hospital environment and equipment (32). These bacteria have also been widely reported in the ICU ward. In the present study, A. baumannii was the most isolated strain of patients admitted to the ICU ward. For the last two decades, $P$. aeruginosa has been a very important pathogen and accounting for a large proportion of nosocomial infections. P. aeruginosa infections are particularly prevalent among burn wound patients (33-35). Determining the pattern of antibiotic resistance is very important for epidemiological surveillance programs and treatment alternatives in burn patients. Antibiotic resistance is the most serious causes for concern, as common bacterial isolates resistant to antimicrobial agents are the most important cause of death in burn patients. In the current study A. baumannii and $P$. aeruginosa were found to be the most resistant isolates. The highest resistance was seen to Ciprofloxacin and the lowest resistance of A. baumannii was seen to Tobramycin and the lowest resistance of $P$. aeruginosa was seen to PiperacillinTazobactam. Whereas in Bayram's study, $A$. baumannii and $P$. aeruginosa resistance to Imipenem was high (30).

$S$. aureus is the third isolate in the list of bacterial isolates. Unlike other studies, the incidence of Penicillin resistance was the highest. Optimal training of burn ward personals, wash and hand hygiene personnel before and after contact with each patient, avoiding crowded appointments, restricting inter-wards hospital exchanges, monitoring the prevention of bacterial infections, attention to antibiotic resistance patterns and effective nosocomial infection control programs all are very important and effective in preventing burn wound infection and its subsequent problems.

\section{Conclusion}

Due to the variable nature of pathogens causing burn wound infection, continuous evaluation and detection of dominant bacterial infections and their sensitivity patterns, in order to modify the drug regimen for proper antibiotic treatment is important to prevent antibiotic resistance and it seems reasonable. An effective infection control program is required in all wards of the burn hospital to prevent the spread of nosocomial burn wound infections. Staffs from all wards of the hospital need to work closely with the hospital acquired infection.

\section{Acknowledgments}

The authors would like to thank hospital lab personnel of the Musa Kazem burn hospital in Isfahan and the bacteriology group of Isfahan University of Medical Sciences for supporting this study.

\section{Funding}

This research did not receive any specific grant from funding agencies in the public, commercial, or not-forprofit sectors.

\section{Conflict of Interest}

Authors declared no conflict of interest.

\section{References}

1. Pujji OJ, Nakarmi KK, Shrestha B, Rai SM, Jeffery SL. The Bacteriological Profile of Burn Wound Infections at a Tertiary Burns Center in Nepal. J Burn Care Res. 2019; 40(6):838-45. [DOI:10.1093/jbcr/irz096]

2. Goudarzi M, Tayebi Z, Dadashi M, Miri M, Amirpour A, Fazeli M. Characteristics of community-acquired methicillin-resistant Staphylococcus aureus associated with wound infections in Tehran, Iran: High prevalence of PVL+ t008 and the emergence of new spa type's t657, t5348, and t437 in Iran. Gene Rep. 2020; 19:100603. [DOI:10.1016/j.genrep.2020.100603]

3. Sharma BR. Infection in patients with severe burns: causes and prevention thereof. Infect Dis Clin Am. 
2007;

[DOI:10.1016/j.idc.2007.06.003]

21(3):745-59

4. Laurie CD, Saffle JR, Chung KK, Cancio LC. Prevention and management of infections associated with burns in the combat casualty. J Trauma Acute Care Surg. 2008; 64(3):S277-86 [DOI:10.1097/TA.0b013e318163c3e4]

5. Magnotti LJ, Deitch EA. Burns, bacterial translocation, gut barrier function, and failure. J Burn Care Res. 2005; 26(5):383-91. [DOI:10.1097/01.bcr.0000176878.79267.e8]

6. Gosain A, Gamelli RL. Role of the gastrointestinal tract in burn sepsis. J Burn Care Res. 2005; 26(1):8591. [DOI:10.1097/01.BCR.0000150212.21651.79]

7. Naderi N, Safdarpour A, Hakemi-Vala M, Masoomi $\mathrm{H}$. Antimicrobial resistance pattern and prevalence of extended spectrum beta-lactamase in non-fermenting gram negative bacteria, isolated from burn wounds: A prospective study from a tertiary burn center. J Burn Care Res. 2020; 41(Supplement_1):S59-60. [DOI:10.1093/jbcr/iraa024.093]

8. Weber J, McManus A. Nursing Committee of the International Society for Burn Injuries. Infection control in burn patients. Burns. 2004; 30(8):A16-24. [DOI:10.1016/j.burns.2004.08.003]

9. Sherertz RJ, Sullivan ML. An outbreak of infections with Acinetobacter calcoaceticus in burn patients: contamination of patients' mattresses. J. Infect. Dis. 1985; 151(2):252-8. [DOI:10.1093/infdis/151.2.252]

10. Stokes MA, Johnson WD. Burns in the Third World: an unmet need. Ann Burns Fire Disasters. 2017; 30(4):243.17.

11. Brink AJ, Richards GA. The role of multidrug and extensive-drug resistant gram-negative bacteria in skin and soft tissue infections. Curr Opin Infect Dis. 2020; 33(2):93-100 [DOI:10.1097/QCO.0000000000000636]

12. Leseva M, Arguirova M, Nashev D, Zamfirova E, Hadzhyiski O. Nosocomial infections in burn patients: etiology, antimicrobial resistance, means to control. Ann Burns Fire Disasters. 2013; 26(1):5.

13. Chan M. Antimicrobial resistance in the European :union: and the world. WHO. 2012.

14. Oncul O, Yüksel F, Altunay H, Açikel C, Çeliköz B, Çavuşlu Ş. The evaluation of nosocomial infection during 1-year-period in the burn unit of a training hospital in Istanbul, Turkey. Burns. 2002; 28(8):73844. [DOI:10.1016/S0305-4179(02)00106-7]

15. Michie KL, Dees JL, Fleming D,et al. The role of Pseudomonas aeruginosa glutathione biosynthesis in lung and soft tissue infection. Infect Immun. 2020. 88(6):e00116-20. [DOI:10.1128/IAI.00116-20]

16. Pourhajibagher M, Partoazar A, Alaeddini M, Etemad-Moghadam S, Bahador A. Photodisinfection effects of silver sulfadiazine nanoliposomes dopedcurcumin on Acinetobacter baumannii: a mouse model. Nanomedicine.2020; 15(05):437-52. [DOI:10.2217/nnm-2019-0315]

17. Pruskowski KA, Akers KS, Chung KK. Diagnosis and treatment of infections in Burns. In: Handbook of Burns Volume 12020 (pp. 299-308). Springer, Cham. [DOI:10.1007/978-3-030-18940-2_23]

18. Ozumba UC, Jiburum BC. Bacteriology of burn wounds in Enugu, Nigeria. Burns. 2000; 26(2):17880. [DOI:10.1016/S0305-4179(99)00075-3]

19. Kaushik R, Kumar S, Sharma R, Lal P. Bacteriology of burn wounds-the first three years in a new burn unit at the medical college chandigarh. Burns. 2001; 27(6):595-7. [DOI:10.1016/S0305-4179(01)000237]

20. Song W, Lee KM, Kang HJ, Shin DH, Kim DK. Microbiologic aspects of predominant bacteria isolated from the burn patients in Korea. Burns. 2001; 27(2):136-9. [DOI:10.1016/S03054179(00)00086-3]

21. Igumbor E, Gwanzura L, Chirara M, Obi C, Muza D. Antibiotic sensitivity and plasmid profiles of Pseudomonas aeruginosa. AJOL. 2000; 46(11):296300. [DOI:10.4314/cajm.v46i11.8573]

22. Xue B, Liu X, Tang M. The change in bacterial flora and antibiotic resistance of bacteria of burn patients in our hospital during 1986-1996. Zhongguo Xiu Fu Chong Jian Wai Ke Za Zhi. 1999; 15(4):309-12.

23. Alaghehbandan R, Rossignol AM, Lari AR. Pediatric burn injuries in Tehran, Iran. Burns. 2001; 27(2):115-8. [DOI:10.1016/S0305-4179(00)000838]

24. Lari AR, Alaghehbandan R, Nikui R. Epidemiological study of 3341 burns patients during three years in Tehran, Iran. Burns. 2000; 26(1):4953.25. [DOI:10.1016/S0305-4179(99)00102-3]

25. 25. Mahon CR, Lehman DC, Manuselis G. Textbook of diagnostic microbiology-e-book. Elsevier Health Sciences; 2018 Jan 18.

26. Institute CLSI. Performance standards for antimicrobial susceptibility testing. M100 S28.

27. Fazeli H, Kamali Dolatabadi R, Taraghian A, Nasr Isfahani B, Moghim S. Genetic characterization of blaSHV/VEB/PER genes in ESBL-producing MDR Klebsiella Pneumonia strains isolated from patients in Isfahan, Iran. Eur Online J Nat. 2015; 4(1): 191. 
28. Qader AR, Muhamad JA. Nosocomial infection in sulaimani burn hospital, IRAQ. Ann Burns Fire Disasters. 2010; 23(4):177.

29. Skibba KE, Mitchell DC, Bell DE. The effective elimination of nosocomial burn wound infections with daily wound care. J Burn Care Res. 2019; 40(Supplement_1):S103-4. [DOI:10.1093/jbcr/irz013.173]

30. Bayram Y, Parlak M, Aypak C, Bayram I. Threeyear review of bacteriological profile and antibiogram of burn wound isolates in Van, Turkey. Int J Med Sci. 2013; 10(1):19. [DOI:10.7150/ijms.4723]

31. Al-Aali KY. Microbial profile of burn wound infections in burn patients, Taif, Saudi Arabia. Arch Clin Microbiol. 2016; 7(2):1-9.

32. Boral B, Unaldi Ö, Ergin A, Durmaz R, Eser ÖK. A prospective multicenter study on the evaluation of antimicrobial resistance and molecular epidemiology of multidrug-resistant Acinetobacter baumannii infections in intensive care units with clinical and environmental features. Ann. Clin. Microbiol. Antimicrob. 2019; 18(1):19. [DOI:10.1186/s12941019-0319-8]

33. Lari AR, Alaghehbandan R. Nosocomial infections in an Iranian burn care center. Burns. 2000 Dec 1; 26(8):737-40. [DOI:10.1016/S0305-4179(00)000486]

34. Darshan BB, Holla R, Kotian S, Unnikrishnan B, Ballal S, Thapar R, Mithra P, Kumar N, Kulkarni V, Kumar A. Clinico-epidemiological profile of burns cases admitted to a tertiary care hospital in a coastal area of South India. Int J Community Med Public Health. $2017 \quad$ Feb 6; 2(4):677-80. [DOI:10.18203/2394-6040.ijcmph20151070]

35. Rezaei E, Safari H, Naderinasab M, Aliakbarian H. Common pathogens in burn wound and changes in their drug sensitivity. Burns. 2011 Aug 1; 37(5):8057. [DOI:10.1016/j.burns.2011.01.019]

\section{How to Cite This Article:}

Haghighifar E, Kamali Dolatabadi R. Bacterial Infections and Antimicrobial Resistance Patterns of Burn Wound Infections: A One Year Study from Burn Hospital, Isfahan, Iran. J Adv Med Biomed Res. 2020; 28 (128):144150

\section{Download citation:}

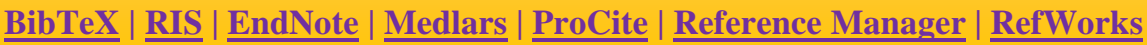

\section{Send citation to:}

\section{Mendeley 2 Zotero (i) RefWorks $\underline{\text { RefWorks }}$}

